\title{
THE EQUAL PAY ACT 1972: BACK TO THE FUTURE?
}

\author{
Martha Coleman*
}

This article takes a fresh look at the Equal Pay Act 1972. Despite problems with the Court's interpretation of the Act, both during the implementation phase and more latterly in the 1986 Clerical Union decision, the article argues that equal pay for work of equal value cases can be taken under it.

\section{INTRODUCTION}

For every dollar earned by a man in New Zealand, women earn on average, just 81 cents. ${ }^{1}$ A number of inter-related factors contribute to this problem including lower levels of experience and seniority and the fact that women are concentrated in a narrow range of generally low paid jobs. ${ }^{2}$ But of all the contributing factors, it has been argued that the single most important is the undervaluation of "women's work". 3

In 1977, as chair of the United States Equal Employment Opportunities Commission, Eleanor Holmes Norton commissioned the National Academy of Sciences to examine "the

* This article was submitted as part of the LLB(Hons) programme at Victoria University. It was awarded the Robert Orr McGechan Memorial Prize in 1996.

1 Statistics New Zealand Quarterly Employment Survey May 1997. This is the ordinary time hourly rate figure. The same survey showed that in terms of total weekly earnings, women earn only 73.8 cents for each dollar earned by a man.

2 For a fuller discussion see P Hyman and A Clark Equal Pay Study Phase One Report (Department of Labour, Wellington, 1987) 12-48. See also M Gunderson Comparable Worth and Gender Discrimination: An International Perspective (ILO, Geneva, 1994) 5-14.

3 M Cornish Equal Pay: Collective Bargaining and the Law (Department of Labour, Toronto, 1986) 4. The use of the term "women's work" is not intended to imply that certain types of jobs are more appropriately performed by women. It is used simply to reflect the extent of the gender segregation of the labour market and that jobs are either normally performed by women or by men, but much less often by both. The terms "men's work" and "mixed work" will also be used to refer to the gender predominance of an occupation (or lack of it). 
issues involved in a 'comparable worth' concept of compensation".4 4 Their report concluded: "not only do women do different work than men, but the work women do is paid less and the more the occupation is dominated by women the less it pays." 5 Other studies have reached similar conclusions showing that the sex of the worker performing the job is the "best single predictor of the compensation for that job, surpassing in importance education, experience or unionisation". 6

Occupational segregation is the main way in which gender-based pay discrimination arising from the undervaluation of women's work, has been institutionalised and maintained. Equal employment opportunities policies aimed at breaking down such segregation, combined with equal pay for like work laws, are one way of ensuring greater equity. However, occupational segregation along gender lines is so entrenched that twothirds of all employed men and women would have to change jobs to eliminate it. ${ }^{7}$ Therefore, the concept of equal pay for work of equal value is a better solution for tackling the low pay and low status of women in gender-segregated work. This would allow comparisons to be made between different kinds of jobs, but jobs to which a similar value can be attributed using gender neutral criteria. Since men and women are normally employed in different jobs, the narrower concept of equal pay for like work is not sufficient to redress the existence of gender bias in pay.

The principle of equal pay for work of equal value is not new. It attained international status following the First World War when it became incorporated in the Treaty of Versailles. ${ }^{8}$ Adopting much of its constitution from the Treaty, the International Labour Organisation (ILO), in 1919, included equal pay for work of equal value as one of its founding principles. ${ }^{9}$ Despite its long standing, the equal value element of the equation has yet to be realised.

New Zealand has introduced three pieces of legislation specifically designed to deal with gender-based pay inequity. The first was the Government Service Equal Pay Act 1960

4 S Evans and B Nelson Wage Justice: Comparable Worth and the Paradox of Technocratic Reform (University of Chicago Press, Chicago, 1989) 37.

5 D Treiman and H Hartmann Women Work and Wages: Equal Pay for Jobs of Equal Value (National Academy Press, Washington DC, 1981) 28.

6 H Remick (Ed) Comparable Worth and Wage Discrimination: Technical Possibilities and Political Realities (Temple University Press, Philadelphia, 1984) ix.

7 As referred to in R Steinberg "A Want of Harmony: Perspectives on Wage Discrimination and Comparable Worth" in H Remick above n 6, 4.

$8 \quad$ Article 427.

9 Article 41. 
which was designed to eliminate separate male and female pay scales in the public service. Twelve years later the Equal Pay Act $1972^{10}$ was passed, applying to the private sector. It resulted in a significant closing of the pay gap ${ }^{11}$ but did not deliver pay equity.

This paper argues that the 1972 Act failed to deliver on its potential. Despite clear evidence that it was intended to overcome the limitations posed by occupational segregation in the implementation of equal pay, it was not interpreted or applied in that light. Frustrated by its perceived ineffectiveness, equal pay campaigners decided to push for new legislation in the mid-1980s. ${ }^{12}$ This goal was finally achieved with the passage of the third piece of legislation, the Employment Equity Act 1990. This Act was short-lived. The incoming National Government repealed the legislation within a few weeks of taking office. New legislation, although possible, is unlikely given the lack of commitment to it by most of the major political parties. ${ }^{13}$ This puts the focus back on the 1972 Act.

One of the problems with the Equal Pay Act 1972 is that it was never clear what the criteria for determining whether or not there was pay discrimination actually meant. This paper identifies the problems in the wording which led to this confusion and argues that despite the ambiguity there is clear evidence that the Act was intended to provide for equal value comparisons.

The paper then examines the last of a small number of cases taken under the Equal Pay Act, ${ }^{14}$ where a narrow interpretation of the Act was taken by the Court. ${ }^{15}$ Although no appeal was lodged at the time, the paper argues the case was wrongly decided. It also argues that since the advent of the Employment Contracts Act 1991, the decision no longer applies, leaving the way clear for new litigation.

How a court should interpret the Equal Pay Act is considered next. The issue of whether the Act provided for the elimination of discrimination between jobs of equal value or merely between like work is discussed. This is followed by an examination of the related issue of the scope of any comparisons, and in particular whether or not comparisons can only be made between jobs covered by the same contract.

10 Hereinafter often referred to as "the Act".

11 The pay gap closed by about 6 points during the implementation period. See P Hyman Women and Economics (Bridget Williams Books, Wellington, 1994) 88.

12 See generally M Cook Just Wages (Coalition for Equal Value Equal Pay, Wellington, 1994).

13 The Alliance is the only party with a firm commitment to enact new legislation on pay equity.

14 Only ten cases were ever taken, three of which related to individuals.

15 New Zealand Clerical Administrative etc IAOW v Farmers Trading Co Ltd \& Others [1986] ACJ 203. 
The final part of the paper deals with the scope of the employer defence to equal pay. Here the paper argues that the approach of the Arbitration Court to this section was wrong in two main respects. First, the Court failed to properly allocate the burden of proof and second, it failed to uphold the proviso that discriminatory reasons could not be used to justify pay differentials.

The paper concludes by suggesting that it is time for another test case. Properly interpreted as requiring equal pay for work of equal value, the Act can be used to challenge the undervaluation of "women's work".

\section{LIKE WORK OR EQUAL VALUE?}

There has never been a consensus over whether the Equal Pay Act 1972 provided for equal pay for like work or equal pay for work of equal value. Elizabeth Orr, a member of the Committee appointed by the Minister of Labour in both 1975 and 1979 to review the implementation of equal pay, argues that the Act embodied the equal value principle. ${ }^{16}$ The wording of the Act and the recommendations of the Commission of Inquiry set up in 1971 to consider the issue are the first two examples given by Orr as demonstrating this intention. The third is that this was the view of employers. In the June 1972 issue of The Employer, the Employers' Federation said "[t]he concept of equal pay calls for employees, regardless of sex, to receive equal rates of pay for jobs of equal value". ${ }^{17}$ The final reason given by Orr was New Zealand's ratification of ILO Equal Remuneration Convention $100^{18}$ which requires that equal pay laws adhere to the equal value principle. ${ }^{19}$

Prue Hyman, a leading New Zealand academic in the area of equal pay, has argued consistently that the wording of the Equal Pay Act 1972 is supportive of the equal value principle. ${ }^{20}$ Margaret Wilson, chair of the Working Group appointed in 1988 to consider

16 E Orr The Equal Pay Scene Revisited (Unpublished, 1986).

17 Above n 16, 3.

18 The Convention was ratified in 1983.

19 Article 2.

20 See for example: P Hyman Women and Economics (Bridget Williams Books, Wellington, 1994) 85; P Hyman "The Law and Practice in New Zealand with regard to the Promotion and Application of Equal Pay" (1990) paper prepared for ILO, 6; P Hyman "Preliminary Evaluation of the Situation with respect to Equal Pay Between Men and Women in the Employment Contracts Act Framework in New Zealand" (1992) paper prepared for Ministry of Women's Affairs, 9 - obtained under the Official Information Act (OIA). 
the need for new legislation on equal pay, agrees that the wording is broad enough to encompass comparisons of different types of work, but says: ${ }^{21}$

[i]f one looks at the evidence surrounding the enactment of the legislation it is probably fair to say that a narrow interpretation was what was envisaged at the time. It is only subsequent experience that has highlighted the inadequacy of this approach.

Others are even more dismissive of the Act's intention. Fran Wright simply states that it did not provide for equal pay for work of equal value, ${ }^{22}$ a viewpoint endorsed by the Department of Labour. In a report to the Minister of Labour, the Industrial Relations Service stated without qualification that "[t]he Equal Pay Act does not address the question of equal pay for work of equal value". ${ }^{23}$ It is, however, an indication of the lack of clarity surrounding this issue that even government departments are not in complete agreement. The Ministry of Women's Affairs considers the Act in principle to be supportive of the principle of equal pay for work of equal value. ${ }^{24}$ An analysis of the wording of the Act reveals the reasons for these differences of opinion.

\section{A The Words of the Act}

"Equal Pay" is defined in the Act as "a rate of remuneration for work in which rate there is no element of differentiation between male employees and female employees based on the sex of the employees". 25 The Act also contains criteria for determining whether or not there is an element of differentiation. ${ }^{26}$ It is in respect of these criteria that the ambiguity arises.

The criteria differ according to the gender predominance of the occupation in question. Where the work is what may be described as "men's work", that is work mainly performed by men, or "mixed work", being work in which neither men nor women predominate, section 3(1)(a) of the Act calls for a consideration of:

(i) The extent to which the work or class of work calls for the same, or substantially similar, degrees of skill, effort, and responsibility; and

21 M Wilson "An Analysis of the Present Situation" in Equal Pay for Work of Equal Value Seminar Papers (Centre for Continuing Education, Victoria University, 1986) 5.

22 F Wright "Equal Pay and the Employment Contracts Act 1991" (1993) 7 AULR 501.

23 Review of the Equal Pay Act (Industrial Relations Service Report to the Minister, 30 June 1992) 7 obtained under the OIA.

24 Report on the Effectiveness of the Equal Pay Act 1972 (Ministry of Women's Affairs, 15 September 1994) 19 - obtained under the OIA.

25 Section 2.

26 Section 3. 
(ii) The extent to which the conditions under which the work is to be performed are the same or substantially similar.

Where the work is exclusively or predominantly performed by women, section 3(1)(b) states that the equal pay rate is the:

... rate of remuneration that would be paid to male employees with the same, or substantially similar, skills, responsibility, and service performing the work under the same, or substantially similar, conditions and with the same, or substantially similar, degrees of effort.

At first sight the wording seems to imply the Act calls for an equal value approach since it requires consideration to be given to the skill, effort and responsibility required in jobs as well as the conditions under which work is performed. These are the criteria normally used in equal value comparisons. ${ }^{27}$ They allow, for example, the interpersonal skills of shop assistants to be compared with the physical skills of truck drivers, and the financial responsibility of an accountant to be compared with a nurse's responsibility for patient care. The kind of skill, effort or responsibility can be different provided the overall level or degree is the same. However, a closer analysis of the wording in section 3(1) raises questions as to whether this approach can be used.

One interpretation of the section suggests that equal value comparisons are permitted in determining the extent of gender bias in "male" and "mixed" occupations, but are not permitted for determining equal pay where the work is exclusively or predominantly performed by women. This interpretation arises because the word "degree" is used in section $3(1)$ (a) but is not used to the same extent in section 3(1)(b), in that it is only used in relation to effort. The use of the word "degree" in relation to "male" and "mixed" jobs suggests that in determining the extent of gender bias, comparisons are not limited to situations where the nature of the skill and responsibility are the same. The absence of the word "degree" from the determination of gender bias in "women's" work implies the opposite. Comparisons here would be limited to instances where men and women are utilising the same or substantially similar kinds of skills, such as would arise through a like work comparison. Support for section 3(1)(b) being limited to like work comparisons also arises from the inclusion of the words "the work". The fact that the rate is to be determined by deciding what would be paid to a man performing "the work" implies like work comparisons only.

The problem with this analysis is that it makes no sense to provide for equal value in "male" and "mixed" occupations when a like work approach can identify gender bias, but disallow equal value where this approach is necessary to enable comparisons between "women's" work and higher paying "male" jobs. It might therefore be argued that the use of

27 F Eyraud et al Equal Pay Protection in Industrialised Market Economies: in Search of Greater Effectiveness (ILO, Geneva, 1993) 5. 
the terms "same" and "substantially similar" in section 3(1)(b) imply "sameness" in a quantifiable sense as well as in essence, thus allowing both an equal value and like work approach. This is the position in Ireland under the Anti-Discrimination (Pay) Act 1974 where "like work" has a generic meaning ranging from "same work" to work "equal in value ... in terms of the demands it makes in relation to such matters as skill, physical or mental effort, responsibility and working conditions." 28

A third interpretation of these two subsections is possible, namely that neither allows for equal value comparisons. Under this interpretation, the use of the word "degree" in section 3(1)(a) is used to denote a concept of comparative value. It does not imply that comparisons can be made between different kinds of skills or responsibilities but simply that where the degree of skill, effort and responsibility is higher, so too should be the pay. The word "degree" is omitted from section 3(1)(b) because the concept of comparative value is encapsulated in the phrase "the rate of pay that would be paid to a male employees". ${ }^{29}$

The phrase "the rate of pay that would be paid to male employees" in section 3(1)(b) creates further ambiguity. Commonly referred to at the time as the "notional male rate", ${ }^{30}$ it is unclear from the section how this rate is to determined. In addition to the issue of whether the criteria call for a consideration of equal value, other related questions arise. Is the rate to be determined by a comparison with the work of an actual man or a hypothetical man? Does the man, actual or hypothetical, need to be employed by the same employer or within the same industry? This question is crucial since the rates of pay of men in male dominated industries, as well as male occupations, are generally higher than those paid to men in female dominated sectors. ${ }^{31}$ And, finally, a question associated with this last one, does the use of the words "rates payable under any instrument" in section 3(1) restrict comparisons under both sets of criteria to work covered by the same instrument?

28 Section 3.

29 Emphasis added.

30 Progress of Equal Pay in New Zealand Report of a Committee appointed by the Minister of Labour (Government Print, Wellington, 1975) 32.

31 See the comparison of male trade rates in male and female dominated industries in S Iversen "Why women get paid less" (1987) 146 Broadsheet 38 . See also above $n 5$. 
These were issues around which there was considerable uncertainty. The 1975 Review Committee said in its report: ${ }^{32}$

[o]f all the sections of the Act, section 3(1)(b) can be regarded as the most difficult to interpret and implement. That this is so is borne out by the number and length of the submissions received by the committee relating to this topic.

Whatever problems there were over the interpretation and implementation of this section, there is clear evidence that it was intended to provide for equal value and not just like work comparisons.

\section{$B$ Intention}

\section{The Commission of Inquiry}

In 1971, the Government set up a Commission of Inquiry charged with inquiring into and reporting on a suitable formula to give effect to the principle of equal pay. Its first term of reference was the requirement to have regard to the provisions of ILO Equal Remuneration Convention $100 .{ }^{33}$ The provisions of this Convention require state parties to adhere to the principle of equal pay for work of equal value. ${ }^{34}$

The Commission recommended that "equal pay" mean: "a rate of remuneration for work in which rate there is no element of differentiation between male and female employees based on the sex of the worker". ${ }^{35}$ Their recommendation bears a close resemblance to the definition of equal remuneration in the ILO Convention where it is defined as "rates of remuneration established without discrimination based on sex." 36 The closeness of the definitions, indicates that the Commission was giving effect to their terms of reference and intended an equal value approach.

It is clear from their report that the Commission were aware of the extent of the problem of occupational segregation and the consequences it has for the delivery of equal pay. The Commission considered there to be "two main labour markets, one for women and one for men, with a third and smaller market where they compete for the same job and same salary on their merits." ${ }^{37}$ Both the Employers' Federation and the Manufacturers' Federation

32 Above $\mathrm{n} 30$.

33 Equal Pay in New Zealand Report of the Commission of Inquiry (Government Printer, Wellington, 1971) 5.

34 Article 2.

35 Above $n$ 33, 20.

36 Article 1(b).

37 Above n 33, 12. 
argued before the Commission that the Australian model should be followed. This model limited the application of the principle of equal pay to the "male" and "mixed" labour markets. ${ }^{38}$ Equal pay, the Federations claimed, should not extend to the "female labour market" identified by the Commission. ${ }^{39}$ The Commission disagreed. They said that the principle of equal pay included the removal of sex discrimination from the rates of pay applying to work exclusively or predominantly performed by women. Those groups should not be "swept under the carpet" and left to have their position determined by market forces. ${ }^{40}$

The Commission developed criteria by which to judge whether or not there was differentiation based on the sex of the worker. Seemingly these criteria were to apply equally to all jobs irrespective of the gender predominance of the work in question. The criteria, which bear a close resemblance to the provisions of section 3(1) of the Act, are:41

(1) The extent to which the work or classes of work call for the same, or broadly similar, degrees of skill, effort, and responsibility.

(2) The extent to which the conditions under which the work is to be performed are the same, or broadly similar.

(3) The rate of remuneration that would be paid to a male employee for the work.

Where the work is exclusively or predominantly performed by women, the Commission said "remuneration should be fixed as though a male with similar skills, responsibility, and service were performing that work". 42 Arguably this point was made to emphasise that all work was to covered by the principles of the Act. It was not intended to operate as a separate definition. However, when the Bill came to be drafted, this point of emphasis was included as a separate definition of the criteria for identifying discrimination in the rates of pay applying in "female" jobs. And, what was intended as general criteria for identifying discrimination in all rates of pay, applied only to "male" or "mixed" jobs. This meant that the reference to "degrees" of skill, effort and responsibility, a more important concept for determining gender bias in the pay rates of those jobs in the "female" labour market since it

38 The Commonwealth Arbitration Commission in Australia said, in bringing in the principle of equal pay in 1969, that it would not apply "where the work in question is essentially or usually performed by females, but is work upon which male employees may also be employed". See 127 CAR 1142, 1158.

Above $\mathrm{n} 33,20$.

Above $\mathrm{n} 33,20$.

41 Above n 33, 21 - 22.

42 Above n 33, $21-22$. 
allows comparisons of different skills, was omitted from the criteria applying to these workers. It is ironic that the attempt by the Commission to clearly emphasise the broad scope of the principle ends up at best confusing the issue, and at worst limiting the scope in exactly the way the Commission was arguing against.

One further aspect of the Commission's report indicates that they intended the equal value principle to apply. Again this relates to the special reference to work that is exclusively or predominantly performed by women. By bracketing these two categories together the Commission must have intended that comparisons be able to be made outside the female dominated occupations. Treating predominantly female occupations in the same fashion as exclusively female occupations recognises that a like work claim, although theoretically possible for workers in the former group, would not necessarily result in "real" equal pay since the pay rates for men engaged in "women's work" are lower than for men in other occupations. ${ }^{43}$

\section{The Equal Pay Bill}

The parliamentary debates during the passage of the Equal Pay Bill fail to shed real light on the issue of legislative intention. Some politicians, such as the Deputy Leader of the Opposition, Hugh Watt, appeared to think that the Bill provided for like work only. He welcomed "the introduction of a Bill that provides for equal pay for equal work".44 Speaking next, Robert Muldoon, the Minister of Finance, talked about equal pay for equal tasks and the difficulties that arise when determining what are in fact equal tasks. ${ }^{45}$ Whether he meant it was difficult because the tasks may be very different, or because it was unclear what constituted "identical" or "substantially identical" work, the words used in the original Bill to denote the scope of comparisons, is unclear.

The use of the words "identical" and "substantially identical" came in for considerable criticism because of the degree of precision they called for ${ }^{46}$ and, following submissions, were changed to "similar" and "substantially similar". It is in referring to this change during the second reading of the Bill that we perhaps get the best insight into legislative intentions.

43 See above $n 31$.

44 NZPD vol 380, 2178, 29 August 1972.

45 Above $n 44$.

46 Those who raised criticisms include: the Council for Equal Pay and Opportunity; National Organisation of Women; New Zealand Employers' Federation; New Zealand Federation of Labour. 
The Minister of Labour, David Thomson, commented that although the substituted words better reflected the spirit of the Bill: ${ }^{47}$

the really significant words of these criteria are not whether the work should be the same, broadly the same, or substantially similar, but the extent to which the work calls for the same or substantially similar 'degrees of skill, effort, and responsibility', in which case the rates of pay should be the same. That really is the essence or substance of equal pay.

This quote clearly suggests that the Minister intended the Act to provide for equal value comparisons. It may also suggest that many of his colleagues either did not understand this, or did not understand the difference.

\section{Review Committee 1975}

In their submissions on the Bill, the National Organisation of Women expressed concern about the idea of a notional male rate. They considered it important that the equal pay rate for women in predominantly female occupations be set by comparison with an actual man, not an imaginary one, in order to avoid arbitrary and possibly lower male rates being set. ${ }^{48}$ The Committee set up by the Minister in 1975 to review progress on the implementation of equal pay agreed. Finding no legislative warrant in section 3(1)(b) for the use of the expression, they said it placed a fictional rather than a real value on women's work and recommended the term no longer be used. ${ }^{49}$ To help the unions and employers with the implementation of section 3(1)(b), the Committee went on to outline what they considered it intended which was to: ${ }^{50}$

establish an appropriate rate of pay for a class of work which is predominantly performed by females as if it were stationed as a male rate to other male rates of pay. This means that the equal pay rate must be slotted into a structure of male rates.

Any problems of comparing dissimilar occupations could, they said, be overcome by comparing the relative degrees of skill, effort and responsibility involved. ${ }^{51}$ The Committee thus expressly interpreted the section as requiring an equal value comparison.

47 NZPD vol 381, 3256, 11 October 1972.

48 Submission of the National Organisation of Women, Wellington, to the NZ Parliamentary Labour Bills Committee on the Equal Pay Bill and the Consequential Amendments (1972) 3.

49 Above n 30, 32.

50 Above n 30, 33.

51 Above n 30, 33. 
The Committee recommended that the Department of Labour issue a guide to employers on the methods and principles to be used in arriving at the equal pay rate. ${ }^{52}$ When finally issued in 1981, the booklet made it clear that equal value comparisons were required. ${ }^{53}$

If you are employing women in jobs that are often done mainly by women - eg typing, waitressing, sewing, then you will need to relate these jobs to comparable male jobs in your establishment. ... Another approach you could take is to carry out an exercise to set a value on the jobs done by female employees in relation to a range of male jobs. This will allow you to determine an appropriate equal pay rate in a situation where men and women are doing quite different work.

\section{Ratification of ILO Convention}

State practice in New Zealand with respect to ratification of international treaties is that treaties are only ratified when domestic laws are already in compliance. ${ }^{54}$ The 1979 Review Committee reported that "the definition of equal pay in the private sector was in conformity with the convention" and, with the possible exception of superannuation schemes, New Zealand law and practice also complied. ${ }^{55}$ New Zealand ratified the ILO Equal Remuneration Convention in 1983 on the understanding that New Zealand laws complied with the equal value provisions of the Convention. ${ }^{56}$ This is further evidence of the Act's original intention.

\section{The Act in Practice}

While there may be disagreement about the intended scope of the Act, there is general agreement that in practice a narrow interpretation was adopted. Hyman identifies a number of factors which gave rise to what she describes as "less than might be expected from the wording". 57 These factors include the difficulties in establishing the hypothetical rate, the undervaluation of women's skills, resource differences between unions and employers, and

52 Equal Pay Implementation in New Zealand Report of the Committee appointed by the Minister of Labour (Government Printer, Wellington, 1979) 36, 77.

53 As referred to in P Hyman and A Clark above n 2, 45.

54 P Hunt and M Bedggood "International Human Rights Law" in G Huscroft and P Rishworth (Eds) Rights and Freedoms (Brookers, Wellington, 1995) 50. See also the statement by the Deputy Secretary of Labour to this effect to the Royal Commission - above n 33, 14.

55 Above n 52, 56.

56 Repeal of the Employment Equity Act 1990: The Application of ILO Convention 100 (Equal Remuneration) to New Zealand Industrial Relations Service Report to the Minister of Labour (18 December 1990) 2.

57 P Hyman "The Law and Practice in New Zealand" (1990) Paper prepared for the ILO, 7. 
a lack of commitment from male trade union leaders. ${ }^{58}$ Another factor identified by Hyman and others was the role of the Arbitration Court ${ }^{59}$ during the implementation period. ${ }^{60}$ Despite having the ability to give interpretations and guidance as to the meaning of the provisions of the Equal Pay Act $1972,{ }^{61}$ the Court consistently failed to do so in any meaningful way, a fact that drew criticism from the 1979 Review Committee. ${ }^{62}$ The Arbitration Court never exercised their own motion jurisdiction and, on the few occasions they were asked for guidance, the guidance given was both minimal ${ }^{63}$ and questionable. ${ }^{64}$

In 1986, the New Zealand Clerical Workers Association ${ }^{65}$ sought a ruling from the Court that the employer parties to the Clerical Workers Award should be required to negotiate over a claim for equal pay for work of equal value. ${ }^{66}$ This was the first time that the argument that equal pay means equal value had expressly been made to the Court. ${ }^{67}$ The Court declined jurisdiction, saying it had no power to do what the union asked. ${ }^{68}$ While this effectively put the lid on further attempts to use the Act for equal value claims, disagreement remained over the scope of the Act.

58 Above $\mathrm{n} 57$. Hyman also makes the point that in fact the implementation of equal pay for like work in some cases was undermined by the use of different job titles for substantially similar work. See also Equal Pay for Work of Comparable Worth: The Experience of Industrialised Countries OECD Labour Market and Occasional Paper No 6 (OECD, Paris, 1991) 25.

59 This includes decisions of the Industrial Commission prior to this body being replaced in the Industrial Relations Amendment Act 1977.

60 See in particular E Orr "The Arbitration Court's Role in Supervising the Equal Pay Act 1972" in Equal Pay for Work of Equal Value Seminar Papers (Centre for Continuing Education, Victoria University, 1986).

61 Section 9.

62 Above n 52, 48.

63 See, for example, the decision in Equal Pay Act New Zealand Retail Grocery and Supermarket Employees - Determination of the Industrial Commission [1975] Book of Awards 4519. Here the Court essentially said that it was for the parties to determine the appropriate standards to determine whether or not sex discrimination existed in rates of pay.

64 See, for example, Dunedin City Council Women's Rest Home Attendants Award [1976] Book of Awards, 7067. This Award contained only female rates and the Court determined the equal pay rate by comparing the work not to male jobs but to rates for female cleaners under another award.

65 This was the official title of the national federation of independent clerical unions. Although not strictly correct, the paper also refers to the Clerical Workers Association as the Clerical Union.

66 Above $\mathrm{n} 15$.

67 Above n 21, 1.

68 Above n 15, 207. 
The view of the Department of Labour was that the case merely "confirmed" that the Act did not address the question of equal pay for work of equal value. ${ }^{69}$ The Ministry of Women's Affairs had a different perspective. ${ }^{70}$

We would prefer to say that the Courts have interpreted the Act as not addressing the question of equal pay for work of equal value. We disagree that this was confirmed by the Arbitration Court in 1986. Their judgment was a very complex one, but a more accurate layperson's interpretation was that if an equal pay case had previously been made and decisions taken, then the case couldn't be re-opened.

Although the Ministry of Women's Affairs interpretation limits the Clerical Union case to its own particular facts, other commentators have argued that any potential in the Act to address equal value was lost as a result of this restrictive interpretation. ${ }^{71}$

The Clerical Union did not appeal the decision. A memo sent by the National Secretary to the Union's Executive suggests the reason for this. ${ }^{72}$ Although initial legal advice to the Union was that the decision was possibly correct, this was not the major factor in the decision not to appeal. The memo makes it clear that the decision was only to be appealed if the decision was "so wrong in law" that a failure to appeal in these circumstances would have opened up the Union to political and industrial criticism. The Union's real agenda is clear from the memo. The case was part of a longer term strategy for new more effective and less confusing equal pay legislation. In that context, losing the case was not considered by the Union to be a bad outcome. ${ }^{73}$

That new legislation has been won and lost. Given the Union decision not to appeal, any future attempts to use the Equal Pay Act will have to find a way to deal with the limits placed on the Act by this case. Changes in the labour relations environment and changes in courts' attitudes to anti-discrimination legislation, creates the potential for this to occur.

69 Above $\mathrm{n} 23,7$.

70 Letter from Ministry of Women's Affairs to the Industrial Relations Service (23 March 1992).

71 See, for example, M Chen Women and Discrimination: New Zealand and the UN Convention (Victoria University Press for the Institute of Policy Studies, Wellington, 1989) 22; OECD report above n 58, 25.

72 RA Memo 1986/17 (26 February 1986).

73 See also the comments of Union Assistant National Secretary in M Cook above n 12, 7. 


\section{III}

THE 1986 CASE

In the early to mid-1980s, the Clerical Union increasingly became aware and concerned that the Equal Pay Act had failed to deliver equal pay to its members. ${ }^{74}$ When clerical industry employers refused to negotiate on the Union's equal pay claim, the Union lodged a case in the Court to test the scope of the Act. The case essentially raised two issues: first, whether the Act remained operative and, secondly, whether the rates of pay in the proposed award gave equal pay to clerical workers.

\section{A The Decision}

\section{Act still operative?}

The Equal Pay Act has been described as an Act which was designed "to end formal pay differentials in the pay of male and female employees ... as a one-off task". ${ }^{75}$ The emphasis in the Act on this one-off implementation process was the very reason why the Court, in the Clerical Union case, was asked whether the Act was still operative. And while the question needed to be asked, it was answered very simply in the affirmative. The Court stated that since section 6(8) requires that every award in force after 1 April 1977 shall provide for equal pay, the Act was still alive. ${ }^{76}$

\section{Equal pay}

The Union argued that section $\mathrm{s} 3(1)(\mathrm{b})$ provided the criteria by which the issue of equal pay in the predominantly female New Zealand Clerical Workers Award should be judged. ${ }^{77}$ The Court responded by saying that section 3 only supplied the criteria for making the determinations provided by section 4 , and that section 4 had no application to the case. ${ }^{78}$ Section 4 contains the mechanism whereby awards containing female rates of pay were to be adjusted during the equal pay implementation process. The employers argued, ${ }^{79}$ and the Court by implication agreed, that since a determination had already been made under

74 New Zealand Clerical Workers Association Submissions to the Labour Select Committee on the Equal Pay Petition (1987) 4; M Cook above n 12, 1-9.

75 Above n 22, 502.

76 Above n 15, 207. Note that section 7 of the Act says that section 6 applies with the necessary modifications to instruments other than awards. This means that it still applies to contracts.

77 New Zealand Federated Clerical, Administrative and Related Workers IAOW Submissions to the Arbitration Court on Equal Pay and the Equal Pay Act 1972 (1986) 7-8, 18-19, 54.

Above $n$ 15, 207.

79 New Zealand Employers' Federation Submissions to the Arbitration Court in the Matter of the Equal Pay Act and the NZ Clerical Award (1986) 3. 
section 4 , the criteria in section 3 no longer applied. They could not be used for any subsequent purpose.

This is clearly wrong. Section 3(1) expressly states that the criteria are to be used for determining the equal pay rate for work "payable under any instrument and for the purpose of making the determinations specified in ... section $4 " .{ }^{80}$ Given the Court's view that all instruments in effect after 1977 must continue to provide for equal pay, section 3 sets out the criteria to determine whether this has been achieved.

Notwithstanding their finding that section 3 did not apply, the Court went on to consider the issue of equal pay. They said that while section 6(8) can be used to amend an award that proposes elements of differentiation in its rates of pay based on the sex of the employees, "it is acknowledged that there is no such differentiation in the present case". ${ }^{81}$ To understand what the Court means by this statement, it is helpful to again refer to the submissions of the parties.

The Union was not arguing about the existence of gender-based differences within the Award but differences between the rates paid to clerical workers under the Award and those paid to male workers under separate awards. ${ }^{82}$ The employers on the other hand argued that since section 3 referred to rates payable under any instrument, ${ }^{83}$ this did not permit consideration of differentiation between any class of work under the Clerical Award and any other award. They said the section was concerned only with differentiation of work within an instrument. ${ }^{84}$ The Court clearly accepted this latter view, hence their comment that the Act contained no powers or provisions to do what the Union asked. ${ }^{85}$

This is one interpretation of the provisions of the Act but it is not the interpretation which the Court should have taken for reasons I will outline later. However, at this point it is important to note the implicit reasoning of the Court since it has an effect on the standing of the decision today.

80 Emphasis added.

81 Above n 15, 207.

82 Above n 77, 54-65.

83 Emphasis in the original.

84 Above n 79, 3.

85 Above n 15, 207. 


\section{B Does The Case Still Apply?}

The employers argued that the parties to the Award fulfilled their obligations under the Equal Pay Act when they negotiated in the classification system to replace the male and female rates. Subsequent approval by the Arbitration Court was considered proof of this responsibility being properly exercised. Where this had occurred, the employers claimed the Act had no effect. ${ }^{86}$ Their views seem to be implicitly accepted in the judgment because the Court appears to hold that where the provisions of section 4 have been met, the only remedies under the Act arise through section 6(8) and section 3(3) which were held to complement one other. ${ }^{87}$ The decision suggests that any remedies are restricted to situations in which there is a reintroduction of overtly male and female rates and classifications. However, it might be argued that the judgment is restricted to those situations where an equal pay exercise had been carried out. The limitation in the decision, that equal pay can only be determined by comparisons with other rates within an instrument, is therefore not a universal limitation. Indeed the employers' submissions accept as much when they say that had equal pay not been properly implemented then various other sections of the Act "may have some current application". 88

It can be argued, therefore, that the case no longer has any effect for two reasons. First, because the decision only applied to awards and awards are a thing of the past, having been abolished by the Employment Contracts Act 1991. Instead everyone is now covered by a contract of employment. ${ }^{89}$ Secondly, although a few individual employees may still have individual contracts based on the provisions of the old awards, no employment contracts have been through the implementation process. Therefore, since the limitation in the 1986 decision is confined to instruments which have been through the implementation process, it does not apply to employment contracts. Whether the Court would or should decide the same way with respect to employment contracts needs to be considered.

\section{THE PROPER INTERPRETATION}

When introduced, the Employment Contracts Bill made no consequential amendments to the Equal Pay Act. Concern was expressed in many of the submissions on the Bill that, as a result, women would no longer be protected from pay discrimination. This led the Government to introduce the Equal Pay Amendment Act 1991. Amongst the amendments was one to the definition of "instrument" to ensure there was no question that the Equal Pay Act

86 Above $n 79,3-4$.

87 Above n 15, 207.

88 Above $\mathrm{n} 79,6$.

89 Employment Contracts Act 1991 - see long title and Part II. 
covered employment contracts within the meaning of the Employment Contracts Act. ${ }^{90}$ However, the substance of the Equal Pay Act was left unchanged, leaving the debate over the issue of like work or equal value and the scope of any comparisons unresolved. Despite past confusion, an interpretation of the Equal Pay Act that conforms with both accepted standards of statutory interpretation and acknowledged international trends and principles in anti-discrimination law, can give the Act some of the clarity and efficacy it has so far lacked.

\section{A A Purposive Approach}

\section{Purposive approach needed}

John Burrows, in what may be described as the standard New Zealand text on statutory interpretation, states that the modern trend in statutory interpretation is towards a purposive approach. ${ }^{91}$ While the use of the term "purposive interpretation" may be new, the concept is not. ${ }^{92}$ Indeed, in New Zealand there has been a long-standing statutory direction to take a purposive approach by according statutes a "fair large and liberal construction and interpretation as will best ensure the attainment of the object of the Act... according to its true intent, meaning and spirit". 93

A purposive approach requires the words of an Act be given a meaning consistent with its statutory purpose, even to the extent of giving words a strained meaning provided the words can reasonably bear such a meaning. ${ }^{94}$ It is particularly important to adopt a purposive approach in interpreting human rights legislation. Human rights legislation is seen as having a special character, being "not quite constitutional but certainly more than ordinary", 95 and as such, should be given "an interpretation to advance its broad purposes". 96 The Equal Pay Act 1972 is an anti-discrimination law and forms part of New Zealand's legislative code for the protection of human rights.

90 See generally Employment Contracts Bill: Implications for the Equal Pay Act 1972 A Joint Report to the Ministers of Labour and Women's Affairs (19 April 1991).

91 JF Burrows Statute Law in New Zealand (Butterworths, Wellington, 1992) 96.

92 F Bennion Statutory Interpretation (2ed, Butterworths, London, 1992) 660.

93 Section 5(j) of the Acts Interpretation Act 1924.

94 Above n 91, 102; above n 92, 559-661.

95 Ontario Human Rights Commission and O'Malley v Simpsons-Sears Ltd [1985] 2 SCR 536, 547.

96 Above $n 95$. 
The importance of adopting a purposive approach to the interpretation of human rights legislation has been accepted in New Zealand. ${ }^{97}$ The same approach has also been held to apply to the interpretation of other social legislation. Referring to the Parental Leave and Employment Protection Act 1987, Palmer J, in a recent decision of the Employment Court, stated that bearing in mind that the Act was "social legislation of a reforming character", nothing should be done to whittle away the important rights it contained. ${ }^{98}$

Commonly, the purpose of an Act will be spelt out in the long title. ${ }^{99}$ The long title to the Equal Pay Act describes it as "[a]n Act to make provision for the removal and prevention of discrimination, based on the sex of the employees, in the rates of remuneration of males and females in paid employment". That it covers prevention as well as removal supports an interpretation that gives the Act an on-going life. Crucial to the scope of this life is what constitutes "discrimination".

In most jurisdictions, discrimination in an employment context means both direct discrimination and indirect discrimination, even when this is not spelt out in the legislation itself. ${ }^{100}$ Indirect discrimination arises where a condition, practice or policy which appears neutral on its face has a differential effect on groups between whom discrimination is prohibited. As the Supreme Court of the United States said in the now famous quote from Griggs v Duke Power: 101

Congress has now provided that tests or criteria for employment or promotion may not provide equality of opportunity merely in the sense of the fabled offer of milk to the stork and the fox. On the contrary, Congress has now required that the posture and condition of the job-seeker be taken into account. It has - to resort again to the fable - provided that the vessel in which the milk is proffered be one that all seekers can use. The Act proscribes not only overt discrimination but also practices that are fair in form but discriminatory in operation.

97 H v E (1985) 5 NZAR 333, 348; Coburn v Human Rights Commission [1994] 3 NZLR 323, 333.

98 Phoenix Freight Ltd $v$ Hodge [1995] 2 ERNZ 100, 118.

99 Above $\mathrm{n}$ 91, 108.

100 See for example Griggs $v$ Duke Power Company (1971) 28 L Ed 2d 158; Jenkins v Kingsgate (Clothing Productions) Ltd (Case 96/80) [1981] ICR 592; above n 95.

101 Above n 100, 164. 
The Equal Opportunities Tribunal, taking a purposive interpretation to the definition of discrimination in the Human Rights Commission Act 1977 in deciding in $H v E$ that sexual harassment was a form of sex discrimination, said: ${ }^{102}$

in our view the treatment of women in the workplace should be no less fair and enlightened in New Zealand than elsewhere in the common law world. Had we felt obliged to record a narrow and restrictive interpretation of this legislation, we would have regarded such a result as out of step with the temperament of modern society.

The same approach should be taken to the meaning of the word discrimination in the Equal Pay Act. It should, in line with the general approach taken in other common law jurisdictions and, in line with the approach taken by the Employment Court under the Employment Contracts Act $1991,{ }^{103}$ be read as incorporating the twin concepts of direct and indirect discrimination. The fact that a pay rate does not overtly discriminate between men and women because the rate is paid to all typists, nurses and shop assistants irrespective of their sex, does not mean the rate is not discriminatory. The effect of paying a rate to those groups of workers which is below the rate paid to comparably valued male jobs, discriminates in practice since it is mainly women who are underpaid. The meaning of discrimination, and the criteria in the Act for determining whether or not there is discrimination, can and should be interpreted purposively. The result is that the Equal Pay Act not only permits but requires the elimination of discrimination in rates of pay where the work performed by women and men is of equal value.

The Court could also confirm the purpose of the Act by considering extrinsic sources such as committee reports and parliamentary debates. ${ }^{104}$ The report of the 1971 Commission of Inquiry shows that an equal value approach was intended. The Commission specifically rejected the idea that comparisons would be limited to those instances in which men and women would be employed in the same kind of jobs. ${ }^{105}$ And, by placing work predominantly as well as exclusively performed by women in the same category, even though like work comparators would be available for the former, the Commission clearly intended the legislation to address the undervaluation of "women's work". As the House of Lords held in Pickstone $v$ Freemans plc, ${ }^{106}$ the fact that a man is employed in the same job and on the same

102 Above $n$ 97, 348.

103 Trilford $v$ Car Haulaways [1996] 2 ERNZ 351.

104 Above n 91, 108-109.

105 Above n 33, 20.

106 [1987] ICR 697. 
pay as a woman, should not prevent her from claiming equal pay for work of equal value. To do so, would, in the words of Lord Keith: ${ }^{107}$

leave a large gap in the equal work provision, enabling an employer to evade it by employing one token man on the same work as a group of potential women claimants who were deliberately paid less than a group of men employed on work of equal value with that of the women.

Hansard reports show that although some parliamentarians may not have really understood what the intended scope of the legislation was, the Minister responsible for the Bill did. Thus, the legislative intention, as demonstrated by the parliamentary debates and the report of the Commission of Inquiry, also suggests that the purpose of the Act was to provide for equal pay for work of equal value and not just equal pay for like work.

\section{Problems with approach of the Employment Court}

The obiter comments of the Employment Court in Trilford $v$ Car Haulaways that the concept of discrimination in section 28 of the Employment Contracts Act 1991 encompasses indirect discrimination are, in the words of Isaacus Adzoxornu, to be welcomed. ${ }^{108}$ However, as Adzoxornu points out, there are problems with the approach of the Employment Court to both direct and indirect discrimination.

In Trilford, the Employment Court endorsed the approach previously taken in $\mathrm{NZ}$ Workers IUOW $v$ Sarita Farm Partnership, ${ }^{109}$ a case concerning discrimination on the grounds of union membership. In that decision, the Court held that in order to establish whether or not there was discrimination required "an examination of the employer's state of mind and motives." 110 In holding, along with the rest of the common law world, that the concept of discrimination includes both direct and indirect discrimination, so too should the Employment Court have followed their approach to the issue of intention. While an intention to discriminate will always be relevant, a lack of intention is irrelevant. As McIntyre J stated in Ontario Human Rights Commission v Simpsons-Sears: ${ }^{111}$

To take the narrower view and hold that intent is a required element of discrimination ... would seem to me to place a virtually insuperable barrier in the way of a complainant seeking a remedy. It would be extremely difficult to prove motive, and motive would be easy to cloak

\footnotetext{
107 Above n 106, 711.

108 "Indirect Discrimination in Employment" [1997] NZLJ 217, 220.

109 [1991] 1 ERNZ 510.

110 Above n 109, 515.

111 Above n 95, 549-550.
} 
in the formation of rules which, though imposing equal standards, could create, as in Griggs $v$ Duke Power $\mathrm{Co}_{0}$ injustice and discrimination by the equal treatment of those who are unequal. Furthermore, as I have endeavoured to show, we are dealing here with the consequences of conduct rather than with punishment for misbehaviour. In other words, we are considering what are essentially civil remedies. The proof of intent, a necessary requirement in our approach to criminal and punitive legislation, should not be a governing factor in construing human rights legislation.

The approach of McIntyre J in that case influenced Cartwright J's view in Northern Regional Health Authority $v$ Human Rights Commission, ${ }^{112}$ that an intention to discriminate was not necessary for conduct to be prohibited under section 19 of the New Zealand Bill of Rights Act $1990 .^{113}$

By requiring a consideration of the employer's motive, the Court are also at odds with the approach of House of Lords as set out in Birmingham City Council v Equal Opportunities Commission ${ }^{114}$ and James $v$ Eastleigh Borough Council, ${ }^{115}$ despite their endorsement in both the Trilford and Sarita Farm Partnership cases of those two decisions. The House of Lords applies a "but for" test to determine whether or not the impugned requirement or condition is discriminatory and this practice is followed by the Employment Court. However, in so doing, the House of Lords makes it clear that the test is an objective not a subjective one. An intention or motive to discriminate was not a necessary condition of liability. ${ }^{116}$ Were that the case, it would mean, as Lord Goff, adopting counsel's argument in Birmingham City Council, pointed out: ${ }^{117}$

it would be a good defence for an employer to show that he discriminated against a woman, not because they intended to, but (for example) because of customer preference, to save money, or even to avoid controversy.

There are further problems with the application of the "but for" test in the Trilford and Sarita Farm Partnership cases. The first really relates to a implicit limitation in the test itself. As Adzoxornu points out, the "but for" test is of limited value where there are multiple reasons for the less favourable treatment. ${ }^{118}$ While this criticism is valid, a recent decision

112 Unreported, 9 July 1997, Auckland, High Court Registry, CP 157/97.

113 Above n 112, 31.

114 [1989] 1 AC 1155.

115 [1990] 2 AC 751.

116 Above n 114, 1193-1194; above n 115, 764-765, 774.

117 Above n 114, 1194.

118 Above n 108, 216. 
of the Employment Appeal Tribunal (EAT) in the UK suggests that a narrow view to causation will not be taken, at least where some discriminatory motive can be ascertained. In Nagarajan v Agnew $w^{119}$ the EAT held that if there are mixed motives for the doing of an act, one or some but not all of which constitute unlawful discrimination, it will be sufficient if the unlawful motive or motives were of sufficient weight to be treated as a cause. They do not have to be the sole cause of the discrimination. ${ }^{120}$ That said, so far the Employment Court gives no consistent sign of a similarly broad approach. In Trilford, Palmer J, in giving the decision of the Court, quotes from Sarita Farm Partnership as follows: ${ }^{121}$

the Court looks also for proof of causal connection between them [the dismissal and the head of prejudice] in the sense that the head of prejudice in issue must be shown to have been the reason which actuated the dismissal, the reason 'but for' which the dismissal is unlikely to have taken place.

Goddard CJ, however, in a more recent decision, Kelly $v$ Tranz Rail, ${ }^{122}$ adopts a better stance. He stated the reason need not be the only one but it must be an operative or causative reason. Unfortunately, he also reiterated that in assessing the employer's reason, the emphasis was on the employer's subjective state of mind, albeit determined objectively. ${ }^{123}$

The second problem with the application of the "but for" test arises as a result of the decisions of both Goddard CJ and Palmer J in Trilford. Goddard CJ states, firstly, that there is no need to distinguish between direct and indirect discrimination and secondly, that the Sarita method should enable the Tribunal to determine whether there has been discrimination. ${ }^{124}$ Palmer J's reaches the same conclusion holding that the approach in Sarita was of equal relevance whatever the form of discrimination. ${ }^{125}$ With respect, this viewpoint demonstrates a lack of understanding of the whole concept of indirect discrimination. Since indirect discrimination does not discriminate on its face but in its effect, rarely will the "but for" test be an appropriate way to test for discrimination. For example, an employer may decide not to give nurses a pay rise, not because they are women, but, because they are nurses. It is, nonetheless, indirectly discriminatory since most nurses

119 [1995] ICR 520.

120 Above n 119, 535. See also Owen \& Briggs v James [1982] ICR 618.

121 Above n 103, 378.

122 [1997] ERNZ 476.

123 Above n 122, 497.

124 Above n 103, 353.

125 Above n 103, 385. 
are women. However, such a decision would not be found to be discriminatory using the "but for" test, especially if there were any male nurses who also missed out on a rise. As Lord Goff, stated in James $v$ Eastleigh Borough Council itself: ${ }^{126}$

the "but for" test is not appropriate for cases of indirect discrimination ..., because there may be indirect discrimination against persons of one sex ..., although a (proportionately smaller) group of persons of the opposite sex is adversely affected in the same way.

Palmer J in Trilford considered there to be compelling force in the argument that a purposive approach should be taken to section 28 of the Employment Contracts Act $1991 .{ }^{127}$ On this basis he declined to restrict the concept of discrimination to direct discrimination despite the lack of express provisions in the Act referring to indirect discrimination. However, Palmer $\mathrm{J}$ failed to follow through on his promise. A truly purposive approach would have also led him to conclude firstly, that motive or intention was not a necessary element of discrimination and secondly, that the "but for" test was inappropriate as a test of indirect discrimination

\section{B Consistency With International Instruments}

Applying other canons of statutory interpretation to the Equal Pay Act 1972 leads to the same result as the purposive approach. One such rule is that wherever possible legislation should be interpreted consistently with international obligations. ${ }^{128}$ The limit to this rule is that where the wording of a statute is contrary to that in the international instrument, but is nonetheless clear and unambiguous, the statute and not the treaty must prevail. ${ }^{129}$

New Zealand has ratified two Conventions which expressly provide for equal pay for work of equal value, the ILO Equal Remuneration Convention 100 and the United Nations Convention on the Elimination of All Forms of Discrimination Against Women (CEDAW). ${ }^{130}$ Given the differing interpretations of the Equal Pay Act, it is fair to say that the Act is not clear and unambiguous. However, while the wording may not be clear, the principle of statutory interpretation is. The ambiguity should be resolved in favour of an interpretation that is consistent with these two conventions.

Above $\mathrm{n} 115,774$.

Above $\mathrm{n} 103,376$.

P Hunt and M Bedggood above $n$ 54, 53.

Ashby $v$ Minister of Immigration [1981] 1 NZLR 222, 229.

Article 11(1)(d). 
Giving the Act an equal value interpretation in line with the two conventions would also be consistent with its legislative history. The provisions of the Act were largely determined, at least in principle, by the recommendations of the Commission of Inquiry, which were, according to the speech of the Governor General in opening Parliament, "substantially adopted". ${ }^{131}$ The first term of reference for the Commission in formulating these recommendations was the requirement to take account of the ILO Convention $100{ }^{132}$ The concept of discrimination under the International Covenant on Civil and Political Rights (ICCPR) is also of importance, particularly in the role it plays in determining the concept of discrimination under the New Zealand Bill of Rights Act 1990.

\section{Consistency With New Zealand Bill of Rights Act}

The main function of the New Zealand Bill of Rights Act 1990, at least as far as legislation is concerned, is as an interpretive tool. ${ }^{133}$ Section 6 of the Bill of Rights Act states that where legislation can be given a meaning consistent with the provisions of the Act, that meaning is to be preferred. Relevant in this instance is section 19 which prohibits discrimination on the same grounds as are prohibited under the Human Rights Act 1993. Included in the prohibited grounds under the Human Rights Act is discrimination on grounds of sex. ${ }^{134}$

Since one of the purposes of the New Zealand Bill of Rights Act 1990 is to affirm New Zealand's commitment to the ICCPR, ${ }^{135}$ not surprisingly, jurisprudence developed under the ICCPR by the United Nations Human Rights Committee is important in determining the meaning of comparable provisions under the New Zealand Act. Like the New Zealand Bill of Rights Act 1990, the ICCPR contains no definition of discrimination. However, the Human Rights Committee, in one of its General Comments, considered that discrimination should have the same general meaning that it does under CEDAW and the Convention on the Elimination of All Forms of Racial Discrimination (CERD). The Committee stated:136

While these conventions deal only with cases of discrimination on specific grounds, the Committee believes that the term 'discrimination' should be understood to imply any distinction, exclusion, restriction or preference on any ground such as race, colour, sex,

NZPD vol 378, 9, 8 June 1972.

Above n 33, 5.

P Rishworth "Affirming Fundamental Values" in G Huscroft and P Rishworth (Eds) Rights and Freedoms (Brookers, Wellington, 1995) 94. 
language, religion, political or other opinion, national or social origin, property, birth or other status, and which has the purpose or effect of nullifying or impairing the recognition, enjoyment or exercise by all persons, on an equal footing, of all rights and freedoms.

This view of the Human Rights Committee was one of the reasons given by Cartwright J for holding, in Northern Regional Health Authority $v$ Human Rights Commission that section 19 of the Bill of Rights Act encompassed both direct and indirect discrimination. ${ }^{137}$ Earlier, Temm J, in Lal $v$ Residence Appeal Authority, ${ }^{138}$ had also found that section 19 included indirect discrimination. However, his judgment suggests he found some difficulty in applying the concept. In that case, Mr Lal claimed he had been indirectly discriminated against because a requirement to hold a trade certificate that was not available in Fiji adversely affected those of Fiji origin. Temm J disagreed, observing: ${ }^{139}$

The requirement to hold a trade certificate to be classified by the Immigration Service as a tailor is not directed at Fijians or any other national or ethnic group. It is a requirement directed at those applicants for a residence permit in New Zealand who apply to be credited with points for their past work experience. Any Fijian citizen who is the holder of a trade certificate as a tailor would be entitled to apply to be so classified. The requirement does not create discrimination on grounds of ethnic or national origin.

The fact that the policy was not directed at Fiji nationals is irrelevant to the concept of indirect discrimination. The issue is not whether the policy was targeted at any particular group but whether or not the policy affected them adversely in comparison to others. The consequences may be entirely unintended and unforeseen but, nonetheless, indirectly discriminatory

The long title to the Bill of Rights Act is important in another respect. The other stated purpose of the Act is to "affirm, protect and promote human rights and fundamental freedoms in New Zealand." This means, as Cooke P, as he was then, has said on more than one occasion, that there is a positive obligation on the courts to develop the law in line with the rights and freedoms contained in the Act. ${ }^{140}$ "Such a measure is not to be approached as if it did not more than preserve the status quo". ${ }^{141}$ Therefore, even if a court was to hold that the

137 Unreported, 9 July 1997, High Court, Auckland Registry, CP 157/97, 24-25.

138 [1997] NZAR 299.

139 Above $\mathrm{n} 138,302$. This reasoning was adopted by the Court in Wheen $v$ Real Estate Institute of New Zealand Unreported, 9 July 1997, Auckland High Court Registry, HC 43/96, 121/96, 30/97, with respect to the indirect discrimination provisions of the Human Rights Act 1993.

140 Ministry of Transport v Noort [1992] 3 NZLR 260, 270; Simpson v A-G [Baigent's Case] [1994] 3 NZLR 667, 676.

141 Ministry of Transport $v$ Noort above n 140, 270. 
1986 Clerical Union case was not limited to its own special facts (which no longer have any relevance in an Employment Contracts Act environment), the issue of the nature and scope of comparisons under the Equal Pay Act must be looked at again. And, in reassessing the case, the Court is bound to interpret the Equal Pay Act consistently with the concept of indirect discrimination arising under the Bill of Rights Act. The Court must hold that the Equal Pay Act provides for equal pay for work of equal value.

\section{International Trends}

International precedent exists for the decision to be re-examined. Equal pay was one of the provisions of the Treaty of Rome, the founding treaty of the European Community, although that Treaty appeared to limit the concept to equal pay for equal work rather than the broader concept of equal value. ${ }^{142}$ The scope of Article 119 was tested in the 1970s in a series of cases taken by Ms Defrenne relating to the retirement age of women working for the Belgian national airline, Sabena. ${ }^{143}$ Under the airline s policy, women were required to retire at 40 whereas men could keep working until normal retirement age. One of the consequences for women was they never qualified for the lucrative company pension.

The Defrenne litigation was symptomatic of the frustration felt by many, including the European Commission and Parliament, over the lack of progress on equal pay and equal treatment, and it provided some of the impetus for the European Community to develop more effective measures. ${ }^{144}$ The first of these measures was the Equal Pay Directive 1975, Article 1 of which says:

... [t]he principle of equal pay for men and women outlined in Article 119 of the Treaty, hereinafter called the 'principle of equal pay', means, for the same work or work to which equal value is attributed, the elimination of all discrimination on grounds of sex with regard to all aspects and conditions of remuneration.

In the second Defrenne case ${ }^{145}$ the ECJ was called on to consider the Equal Pay Directive. The Court suggested the Directive extended the narrow criterion of equal work contained in Article 119. ${ }^{146}$ However, consistent with the view that secondary legislation

142 Treaty of Rome Article 119.

143 Defrenne $v$ Belgium [1971] Case 80/70 ECR 445; Defrenne v Sabena [1976] Case 43/75 ECR 455; Defrenne v Sabena [1978] Case 149/77 ECR 1365.

144 E Szyszczak "Pay Inequalities and Equal Value Claims" (1985) 48 Modern Law Review 139, 140141.

145 Defrenne v Sabena [1976] Case 43/75 ECR 455.

146 Above n 145, 473. 
is not normally interpreted as derogating in any way from the primary provision, ${ }^{147}$ a later case held that the Directive simply "facilitate[s] the practical application of the principle of equal pay ... and in no way alters the content or scope of that principle as defined in the Treaty". ${ }^{148}$ Equal pay was held to mean "equal pay for work of equal value" all along.

The issue of like work or equal value has also been reconsidered in Australia. Despite its decision in 1969 that the equal pay principles should not apply to work "essentially or usually performed by females", three years later the Australian Conciliation and Arbitration Commission changed its mind. ${ }^{149}$ In 1972 representations were made to the Commission by unions and women's organisations. They claimed that only an estimated $18 \%$ of the female workforce had received equal pay and asked for an extension of the principle along the lines provided for in the ILO Equal Remuneration Convention. ${ }^{150}$ The Commission responded: ${ }^{151}$

... [i]n our view the concept of 'equal pay for equal work' is too narrow in today's world and we think the time has come to enlarge the concept to 'equal pay for work of equal value'. This means that award rates for all work should be considered without regard to the sex of the employee.

Influencing the change of view of the Commission was the passage and nature of the New Zealand Equal Pay Act. ${ }^{152}$

Developments in Europe and Australia over the scope of equal pay are just an example of developments in anti-discrimination law generally. As Thorp J said when referring to Canadian decisions in support of his broad purposive approach in Coburn v Human Rights Commission: "[t]hese show a clear trend towards increasing the ambit and coverage of the anti-discrimination provisions in the Canadian human rights legislation". ${ }^{153}$ If impetus were needed to re-examine the scope of the Equal Pay Act, the New Zealand Bill of Rights Act provides such impetus. In the re-examination, the international trend not just in equal pay but in anti-discrimination law generally should be heeded.

147 E Ellis European Community Sex Equality Law (Clarendon Press, Oxford, 1991) 97.

148 Jenkins $v$ Kingsgate (Clothing Productions) Ltd Case 96/80 [1981] ICR 592, 608.

149 National Wage and Equal Pay Cases (1972) 147 CAR 172.

150 C Short "Equal Pay - What Happened?" (1986) 28(3) Journal of Industrial Relations 315, 319.

151 Above n 149, 178.

152 Above $n$ 149, 177.

153 Above $\mathrm{n} 97,335$. 


\section{$V$ SCOPE OF COMPARISONS AND DEFENCES}

\section{A Scope of Comparisons}

Almost as critical as whether the Act provides for equal pay for like work or work of equal value, is the scope of the equal value requirements. Is equal value limited to the provisions of a single instrument, as the Court held in the 1986 Clerical Union case? Is there scope for comparing rates between different work sites or even different employers? Are the equal pay rates to be struck by comparisons with actual men only or is there room for hypothetical comparisons? These are all questions that need to be addressed.

The Ministry of Women's Affairs stated in a report for the Minister that it is not clear what types of complaints or cases it is possible to put through under the Equal Pay Act. They go on to say that many commentators, including the Department of Labour, suggest that the Act does not apply across individual or collective contracts. ${ }^{154}$ The reason for this is that the wording of section 3 refers to "rates of remuneration ... payable under any instrument", 155 which, they argue, does not allow for comparisons between instruments. In other words, the Department of Labour believe that the Act requires only equal pay within the terms of any single instrument or, using today's vernacular, any single contract.

This viewpoint is wrong for several reasons. First, because the Act was always intended to operate in terms of individual contracts of employment. In introducing the Bill, the Minister of Labour said "equal pay shall be provided in instruments of all types covering employer-employee relationships". ${ }^{156} \mathrm{He}$ emphasised this again in the second reading when he said "the Bill applies to all actual rates of remuneration, however fixed". ${ }^{157}$ The only exception to this universal coverage is where an individual contract fixes a rate special to an employee based on that employee's special qualifications, experience or other qualities, provided the fixing of that rate is in itself not discriminatory. ${ }^{158}$ This clause has caused problems over the implementation of equal pay, ${ }^{159}$ but this does not in itself mean that individual contracts are outside its coverage. Nor was this the position of the Arbitration Court which has considered cases relating to

154 Above n 24, 5. See also Comments on the Draft Paper on the Equal Pay Act A letter to Ministry of Women's Affairs (5 February 1993) 4-5, - obtained under the OIA.

Emphasis added.

Above n 44, 2177.

Above n 47, 3232.

Section 2(2). See also above 44, 2177.

See, for example: above n 24, 11; above n 52, 50-52. 
equal pay in individual contracts. ${ }^{160}$ Moreover, it was also clearly the intention of the Government that the Act should continue to cover individual contracts when, as a result of the Employment Contracts Act, they amended the definition of "instrument" in the Equal Pay Act to expressly state it covered contracts.

The second reason why equal value does not just apply to rates within an instrument is that under such a scenario equal pay may well be denied to those in predominantly and exclusively female occupations and industries since there may be no male rates or male jobs to compare to under the contract. Again the Act is quite explicit that equal pay is to apply to all work, including that performed by women in the female intensive industries, a fact pointed out by the Minister of Labour in debates on the Bill. ${ }^{161}$

The issue of whether or not differences in rates of pay existing under different collective agreements should be allowed arose in the United Kingdom in a case finally decided by the European Court of Justice. ${ }^{162}$ Ms Enderby was a speech therapist employed by a health authority. She claimed equal pay with two male comparators, a clinical psychologist and a pharmacist, whose rates of pay were set under separate collective agreements. At issue was whether or not it was justifiable to pay different rates for work of equal value if the differences were arrived at as a result of separate collective bargaining processes, and if these separate arrangements had no internal discriminatory effects. The employers argued that separate agreements was a "material factor" unrelated to sex which justified differences in rates of pay. ${ }^{163}$ The Court held that separate collective agreements could not justify differences in rates of pay. To do so, they said, would be to provide a very easy way to circumvent the Act. ${ }^{164}$ The same reasoning must apply here.

The third reason why the Act should not be read as denying comparisons across contracts, at least in the way meant by the Department of Labour, is that there is no obligation in the Act to make a comparison with an actual man, particularly where the work is predominantly or exclusively performed by women. The use of the word "would" in section $3(1)$ (b) means that the rate is discriminatory if it is not the rate that would be paid to a man. The Act does not require an actual comparison, although this is presumably one method by which this might be determined. Other possibilities include a comparison with a

160 Inspector of Factories v DF Jones [1979] ACJ 71; Inspector of Factories $v$ Ford Motor Company [1979] ACJ 73; Wellington Amalgamated Society of Shop Assistants and Related Trades IUOW $v$ Irvin and Stern Ltd [1978] ACJ 309.

161 See, for example, above $n 47,3232$.

162 Enderby $v$ Frenchay Health Authority (Case C-127/92) [1994] ICR 112.

163 This is a defence to an equal pay claim under the UK Act. See section 1(3).

164 Above $\mathrm{n} 162,163$. 
male pay line ${ }^{165}$ or proxy comparisons. ${ }^{166}$ Therefore, the words "under any instrument" do not mean that comparisons can only be drawn with other rates in that instrument. It simply means that each rate in every instrument must contain no element of gender bias. The bottom line is that the criteria need to be interpreted in light of the overall purpose of the Act, the elimination of discrimination. Limiting the operation of equal value to rates within instruments does not achieve that aim.

Not only does the Act not restrict the assessment of discrimination to comparisons of wage rates within an instrument, but arguably on occasions the Act may require comparisons outside the employer. This is certainly the view of the ILO who, in a press release commenting on the progress in equal pay, said that in light of the particular difficulties of ensuring equal remuneration in industries employing mostly women, "it is essential to have a basis of comparison outside the limits of the establishment or enterprise concerned". ${ }^{167}$ Arguably, the House of Lords' decision in Yorkshire County Council $v$ Ratcliffe $^{168}$ also supports this view in that they acknowledged that the low wages paid in sex-segregated female labour markets were tainted with sex discrimination. Therefore the elimination of discrimination, as required by the 1972 Act, obliges comparisons not just with male jobs but with jobs in male industries. Whether or not the Court would be prepared to go this far in light of the enterprise basis of bargaining now existing under the Employment Contracts Act is uncertain.

\section{B The Operation of Section 2(2)}

As mentioned earlier, section 2(2) is the one exception to the universal application of the Act to all pay rates. This section applies only to individual contracts and allows for special rates to be paid for "special qualities" such as qualifications and experience. There is a proviso. The special rate of remuneration must not involve any discrimination in relation to that employee, or any other, based on sex.

165 Under such a process the value of male jobs would be established using gender neutral criteria and a pay line drawn reflecting average male pay. The rates of pay for the female jobs would then, based on their value according to the same criteria, be adjusted to reflect average male pay.

166 This is similar to the approach adopted by the Commission in the Dunedin City Council Rest Attendants case. However, unlike that case the comparator should be the male rate, not the female rate.

167 "Progress in Equal Pay Linked to General Status of Women and Men in Society, ILO Study Concludes" ILO Press Release (14 May 1986) - obtained under the OIA. 
Two problems have been identified in relation to this section. ${ }^{169}$ The first relates to the generality of the exemption since it removes the obligation to determine what would constitute equal pay before identifying factors special to individual employees. This makes it very difficult to establish whether or not discrimination exists. The second criticism relates to the broad interpretation by the Court to what constitutes "special qualities" which means an employer is always able to find a factor to justify a pay differential. While agreeing in general terms with these criticisms, I would place the emphasis slightly differently. An analysis of the cases under the Act shows that not only did the Arbitration Court take a broad view of what constituted "special qualities", they failed to properly apply the limitation expressed in the section, that the application of the special rate must not involve any discrimination. The analysis also shows that any difficulties that exist in trying to distinguish special qualities from discrimination were compounded by the Court's failure to properly allocate the burden of proof.

\section{Burden of proof}

It is possible to be critical generally of the approach taken by the Court to the burden of proof. Not only did they hold that the standard of proof was higher than the normal civil standard, ${ }^{170}$ but they held that it remained on the applicant throughout. Most other jurisdictions, at least insofar as indirect discrimination is concerned, have held that once differences in pay have been established, it falls on the employer to show that these differences are not discriminatory. ${ }^{171}$

In addition to this general criticism of the Court's approach to the burden of proof, particular criticism can be levelled at the allocation of the burden of proof in respect to section 2(2). The section operates as an exception to the principles established in the Act, and the general rule of evidence is that exceptions must be established by those who rely on them. ${ }^{172}$

169 P Hyman "Equal Pay for Women After the Employment Contracts Act: Legislation and Practice - The Emperor With No Clothes" for Victoria University Industrial Relations Centre Seminar on Women and Work: Issues for the 1990s (1993) 7; above n 24, 10-11.

170 New Zealand (Except Northern Industrial District) Retail Butchers Award (1974) ACJ 153, 155. The Court said that the union had to show with "some certainty" not just prove on the balance of probabilities.

171 See for example: Ontario Human Rights Commission and O'Malleyv Simpsons-Sears above n 95, 558559; Handels-OG Kontorfunktionaerernes Forbund I Danmark $v$ Dansk Arbejdsgiverforening (acting for Danfoss) (Case 109/88) [1989] IRLR 532, 536; Griggs v Duke Power above n 100, 165. Note that the shifting of the burden to the employer in Griggs $v$ Duke Power was reversed in a later case Wards Cove Packing $v$ Atonio (1989) $104 \mathrm{~L}$ Ed 2d 733, but has been subsequently reinstated by the Civil Rights Act 1991. 
The Employers' Federation, in their comments on the Bill, were critical of the section for this very reason. They said that it placed "an implied onus of proof on an employer ... to show that the rate does not involve any sex discrimination vis a vis any other contract in order to be excluded from the Bill". ${ }^{173}$ In responding to this criticism, the Minister of Labour said this was "no different from the normal application of the onus of proof. It is a basic rule of evidence that matters of justification and excuse must be established by a defendant". ${ }^{174}$ Unfortunately the Court, in applying this section, chose not to follow the ordinary rules of evidence.

\section{General problems in the application}

Criticism of the Court's approach to section 2(2) is not just confined to the issue of the burden of proof as the decision in Inspector of Factories $v$ DF Jones ${ }^{175}$ shows. Ms Deverick and $\mathrm{Mr}$ Robertson, the workers in question, were both employed at about the same time as accountant/clerks. The work performed by each was broadly similar. Ms Deverick had higher formal qualifications than Mr Robertson. He, on the other hand, had at least ten years' experience, although this experience appears to be in related but not necessarily the same kind of posts. At the interview, Ms Deverick asked for and was granted a salary of $\$ 5,000$. Mr Robertson would not accept a salary lower than he had received at his previous post. His salary was fixed at $\$ 7,200$. The Court said: ${ }^{176}$

... [w]e are satisfied that the differentiation was solely due to lack of experience on the one hand as against ten years' (or more) extensive experience on the other hand, plus some similarity in academic qualification. We are not, therefore, satisfied that the claim under the Equal Pay Act has been established.

This decision was criticised by the 1979 Review Committee. Considering the situation to be the outcome of the operation of a dual labour market where fewer job opportunities present themselves to women, the Committee were at a loss to understand how this could be used to justify differential rates, especially when the elimination of such differences was a major aim of the Equal Pay Act. ${ }^{177}$

173 Submissions of the New Zealand Employers' Federation to the Labour Committee of the House of Representatives on the Equal Pay Bill (1972) 5.

174 Above $n$ 47, 3234.

175 [1979] ACJ 71.

176 Above $\mathrm{n} 175,72$.

177 Above n 52, 50. 
Their view gets support from a decision of Lord Denning made at the same time where he said: ${ }^{178}$

... an employer cannot avoid his obligations ... by saying: "I paid him more because he asked for more" or "I paid her less because she was willing to come for less". If such excuses were permitted, the Act would be a dead letter. Those are the very reasons why there was unequal pay before the statute. They are the very circumstances in which the statute is intended to operate. Nor can an employer avoid his obligations by giving reasons as to why he submitted to extrinsic forces. As for instance by saying: "He asked for that sum because it was what he was getting in his previous job." or "He was the only applicant for the job so I had no option". In such cases the employer may beat his breast, and say: "I did not pay him more because he was a man. I paid it because he was the only suitable person for the job. Man or woman it made no difference to me." Those are reasons personal to the employer. If any such reasons were permitted as an excuse, the door would be wide open. Every employer who wished to avoid the statute would walk straight through it.

Lord Denning's comments in Clay Cross v Fletcher reinforce the importance of taking a purposive approach to interpreting acts such as the Equal Pay Act. Section 2(2) expressly requires such an approach by the inclusion of the proviso that the payment of a special rate in respect of special qualities must not involve any element of sex discrimination. An analysis of overseas equal pay and discrimination cases demonstrates the total inadequacy of the Court's approach to this section.

In order to establish that differential rates for the same work or work of equal value are not discriminatory but have arisen for other legitimate reasons, such as the existence of "special qualities", courts overseas have taken the position that the reasons for the pay differential must be objectively justified. Objective justification means the reason must correspond to a real need, and be both appropriate and necessary for the achievement of that legitimate objective. ${ }^{179}$ It is not sufficient that there was no intention to discriminate or that the employer thought that their reasons for paying a higher rate were adequate. ${ }^{180}$ Even when the need is legitimate, the concept of necessity means the measures taken must be proportional to that end. ${ }^{181}$

Clay Cross v Fletcher [1979] ICR 1, 5.

180 See, for example: Enderby $v$ Frenchay Health Authority above $\mathrm{n}$ 162; Hampson $v$ Department of Education and Science [1989] ICR 250; Webb v EMO Air Cargo (UK) Ltd [1993] ICR 175.

181 Above n 179. 
This means, for example, that an employer is not justified in rewarding greater experience in a man, unless it can be shown that his experience is necessary for the performance of the job. Arguably in the DF Jones case it was not, since the facts suggested that both jobholders were performing a similar job and that his prior experience was not of an identical nature. Even experience in the particular post will not be a gender neutral factor, unless it can be established there is a relationship between experience and performance. ${ }^{182}$ Moreover, where experience is considered relevant, the principle of proportionality means that unless the whole pay differential can be justified by this rate, it will still be discriminatory. ${ }^{183}$ On this basis, it is hard to justify the nearly $50 \%$ higher rate paid to the man in DF Jones, even if his additional experience was considered relevant. ${ }^{184}$

The operation of market forces, another of the "special qualities" issues at stake in the section 2(2) cases under the Equal Pay Act, ${ }^{185}$ has been accepted overseas as a legitimate defence to unequal pay, ${ }^{186}$ but not where the market forces are themselves tainted with sex discrimination. ${ }^{187}$ This places an important limitation on the operation of this factor. The examples arising under the Equal Pay Act of men being paid more because they were previously paid more, would not succeed although differences due to recruitment and retention may. ${ }^{188}$ Again the principle of proportionality applies so that all the difference must be able to be explained by the employer on this basis. ${ }^{189}$

Section 2(2) is considered to be a major barrier to the efficacy of the Equal Pay Act, even for like work claims. ${ }^{190}$ There is no doubt that were the Court to continue to follow the same approach in future, this would, to use Lord Denning's words, leave the door wide

182 Nimz v Freie und Hansestadt Hamburg [1991] IRLR 222.

183 See, for example, the Court of Appeal decision in Enderby $v$ Frenchay Health Authority [1992] IRLR 15 where it was held that only $10 \%$ of the differential in pay rates between speech therapists and pharmacists could be attributed to recruitment and retention issues.

184 This criticism of the case was made by the Review Committee - see above $\mathrm{n}$ 52, 50.

185 This was an issue in DF Jones and also in a complaint referred to the Labour Department (see above $n 24,14$ ) where men were arguably paid more because they had been receiving higher pay in their previous jobs.

186 Rainey $v$ Greater Glasgow Health Board [1987] ICR 129; Bilka-Kaufhaus GmbH v Weber Von Hartz above $\mathrm{n} 179$.

187 Ratcliffe $v$ North Yorkshire County Council [1995] above $\mathbf{n} 168$.

188 Rainey $v$ Greater Glasgow Health Board above $\mathbf{n} 187$.

189 Above $\mathrm{n} 183$.

190 Above n 169, 7-8. 
open for employers to flout the Act. However, a proper approach by the Courts to the section would help to minimise some of the concerns.

\section{CONCLUSION}

Despite the evidence that the Equal Pay Act 1972 was intended to redress pay discrimination in "women's work" by requiring equal value comparisons, the Act was not interpreted in this light. But this does not mean that if another case were taken today, the approach of a court would be the same.

Nearly 25 years have passed since the Equal Pay Act was enacted. In that time, and particularly over the last ten years, there have been major jurisprudential developments in human rights and anti-discrimination law, greater recognition is given to the importance of international treaties, and New Zealand now has a Bill of Rights Act. The Bill of Rights Act not only obligates courts to re-consider past decisions, but, in this context, requires courts to interpret the Equal Pay Act consistently with the purpose of eliminating both direct and indirect discrimination against women.

The fact that the Equal Pay Act can be used to challenge the undervaluation of women's work, does not mean that many of the other criticisms of the Act are unfounded. ${ }^{191}$ Notwithstanding these limitations, the unlikelihood of better legislation means that the potential of the Act should be put to the test. The United Kingdom Equal Pay Act 1970 has been the subject of consistent criticism over the years. ${ }^{192}$ Nonetheless, used strategically, both legally and industrially, it still has been able to deliver significant gains for women workers. ${ }^{193}$ The repeal of the Employment Equity Act 1990 and passing of the of the Employment Contracts Act 1991, have combined to create, within the politics of employment,

191 These criticisms include the fact that numerous sections of the Act are no longer relevant, that the complaint process is obscure and the remedies a little uncertain. See, for example: P Franks "Comment on Prue Hyman's Paper on Equal Pay" (15 January 1993) obtained under the OIA; Industrial Relations Service "Comments on the Draft Paper on the Equal Pay Act" (5 February 1993) obtained under the OIA; above $n 24$.

192 See, for example, Equal Treatment for Men and Women: Strengthening the Acts (Equal Opportunities Commission, Manchester, 1988); Request to the Commission of the European Communities in Relation to the Principle of Equal Pay (Equal Opportunities Commission, Manchester, undated).

193 For example, the Act has provided the impetus for new classification and job evaluation systems being introduced for nurses and for local authority workers. Many unions also use successful claims to negotiate new pay rates into collective agreements, such as recently occurred for clerical workers and shop assistants in the electricity industry. 
a culture that pays little, if any, attention to issues of discrimination in pay. ${ }^{194}$ A successful case under the New Zealand Equal Pay Act 1972 may help to restore equal pay issues to the negotiating agenda for both individual and collective contracts.

194 For a summary of what has happened to women's pay under the Employment Contracts Act see M Coleman "Pay Equity: Hard Work Down Under" in J Gregory, A Hegewisch \& R Sales Women, Work and Inequality: The Challenge of Equal Pay in a Deregulated Labour Market (MacMillan, forthcoming). 